IZA DP No. 6585

Fiscal Union in Europe? Redistributive and Stabilising Effects of an EU Tax-Benefit System

Olivier Bargain Mathias Dolls

Clemens Fuest

Dirk Neumann Andreas Peichl

May 2012
Nico Pestel

Sebastian Siegloch 


\title{
Fiscal Union in Europe? Redistributive and Stabilising Effects of an EU Tax-Benefit System
}

\author{
Olivier Bargain \\ Aix-Marseille School of Economics, \\ IZA and CEPS/INSTEAD \\ Mathias Dolls \\ IZA and University of Cologne \\ Clemens Fuest \\ University of Oxford, University of \\ Cologne, CESifo and IZA \\ Dirk Neumann \\ IZA and University of Cologne
}

\author{
Andreas Peichl \\ IZA, University of Cologne, \\ ISER and CESifo
}

Nico Pestel

IZA and University of Cologne

Sebastian Siegloch

IZA and University of Cologne

\author{
Discussion Paper No. 6585 \\ May 2012
}

IZA

P.O. Box 7240

53072 Bonn

Germany

Phone: $+49-228-3894-0$

Fax: +49-228-3894-180

E-mail: iza@iza.org

\begin{abstract}
Any opinions expressed here are those of the author(s) and not those of IZA. Research published in this series may include views on policy, but the institute itself takes no institutional policy positions.

The Institute for the Study of Labor (IZA) in Bonn is a local and virtual international research center and a place of communication between science, politics and business. IZA is an independent nonprofit organization supported by Deutsche Post Foundation. The center is associated with the University of Bonn and offers a stimulating research environment through its international network, workshops and conferences, data service, project support, research visits and doctoral program. IZA engages in (i) original and internationally competitive research in all fields of labor economics, (ii) development of policy concepts, and (iii) dissemination of research results and concepts to the interested public.
\end{abstract}

IZA Discussion Papers often represent preliminary work and are circulated to encourage discussion. Citation of such a paper should account for its provisional character. A revised version may be available directly from the author. 


\section{ABSTRACT \\ Fiscal Union in Europe? Redistributive and Stabilising Effects of an EU Tax-Benefit System *}

The current debt crisis has given rise to a debate about deeper fiscal integration in Europe. The view is widespread that moving towards a 'fiscal union' would have a stabilising effect in the event of macroeconomic shocks. In this paper we study the economic effects of introducing two elements of a fiscal union: Firstly, an EU-wide tax and transfer system and secondly, an EU-wide system of fiscal equalisation. Using the European tax-benefit calculator EUROMOD, we exploit representative household microdata from 11 Eurozone countries to simulate these policy reforms and to study their effects on the distribution of income as well as their impact on automatic fiscal stabilisers. We find that replacing one third of the national tax and transfer systems by a European system would lead to significant redistributive effects both within and across countries. These effects depend on income levels and the structures of the existing national tax and transfer systems. The EU system would improve fiscal stabilisation especially in credit constrained countries. It would absorb between 10 and 15 per cent of a macroeconomic income shock. Introducing a fiscal equalisation system based on taxing capacity would redistribute revenues from high to low income countries. The stabilisation properties of this system, however, are ambiguous. This suggests that not all forms of fiscal integration will improve macroeconomic stability in the Eurozone.

JEL Classification: $\quad \mathrm{H} 2, \mathrm{H} 3, \mathrm{~J} 22$

Keywords: European income tax, automatic stabilisation, fiscal union

Corresponding author:

Andreas Peichl

IZA

P.O. Box 7240

53072 Bonn

Germany

E-mail: peichl@iza.org

\footnotetext{
* Preliminary version of a paper prepared for the $56^{\text {th }}$ Panel Meeting of Economic Policy, October 2012. This paper uses EUROMOD version D16. Here, the ECHP and EU-SILC were made available by Eurostat; the Austrian version of the ECHP by Statistik Austria; the PSBH by the University of Liège and the University of Antwerp; the IDS by Statistics Finland; the EBF by INSEE; the GSOEP by DIW Berlin; the Living in Ireland Survey by the ESRI; the SEP by Statistics Netherlands; the Greek HBS by the National Statistical Service; the SHIW by the Bank of Italy and the EBF by INSEE. None of the institutions cited above bear any responsibility for the analysis or interpretation of the data reported here. Peichl is grateful for financial support by Deutsche Forschungsgemeinschaft DFG (PE1675). We are indebted to all past and current members of the EUROMOD consortium for the construction and development of EUROMOD. The usual disclaimer applies.
} 


\section{Introduction}

The process of European unification, which started with the creation of the European Coal and Steel Community in 1951, has slowly but surely moved into the direction of increasing economic and political integration. The creation of a customs union and a common market followed, and the adoption of a single currency in the European Monetary Union (EMU) in 1999 was the latest major step (Sapir, 2011). But EMU is unlikely to be the final step. Proponents of deeper political integration in Europe have repeatedly argued that the European Union (EU) needs a larger budget and the right to levy taxes. For instance, Sijbren Cnossen argues in favour of "a federal government with real taxing powers and financial leverage over the Member States to mitigate adverse effects that might arise from Member State tax policies" (Cnossen, 2001, p. 466f). Lambert (2011) goes even further and develops a normative concept of an equitable EU tax redistribution system.

Until recently the idea of introducing federal fiscal structures in the EU was mostly discussed in academic circles and think tanks but played only a minor role in the policy debate. However, the current debt crisis in the Eurozone has brought the idea of deeper fiscal integration to the top of the European policy agenda. Many observers argue that the currency union cannot survive unless it is complemented by a 'fiscal union'. The concept of creating a fiscal union has many interpretations, ranging from the rather limited approach of introducing a set of balanced budget rules to the more ambitious project of creating a federal government with significant tax and spending powers comparable to existing federations like the US (see e.g. Bordo et al., 2011, Fuest and Peichl, 2012).

While deeper fiscal integration in Europe is thus a widely debated issue, little is known about its economic implications. This paper contributes to filling this gap by analysing the economic effects of two key elements of fiscal integration, i) the introduction of an EU-wide integrated tax and transfer system which partly or fully replaces the existing national systems and ii) the introduction of a system of fiscal equalisation.

Our analysis is based on harmonised microdata and we employ the European tax-benefit calculator EUROMOD which uses harmonised and representative household microdata and allows calculating taxes, transfers and disposable incomes for each household type and country. Our analysis includes 11 Eurozone countries. ${ }^{2}$ EUROMOD allows us to run counterfactual simulations so that we can analyse policy reforms and their effects on tax revenues, the income distribution and labour supply. We proceed as follows. First, we construct a European tax and transfer system, which can be interpreted as an average of the national tax and transfer systems. The system is designed such that it generates the same net revenue on the EU level but not necessarily at the level of each member state. Second, we consider various scenarios where the

\footnotetext{
2 These are the founding members of the EMU (except Luxemburg) and include Austria, Belgium, Finland, France, Germany, Greece, Ireland, Italy, the Netherlands, Portugal and Spain. In the following we will refer to this group as 'the EU', neglecting that the European Union has 27 member countries. We focus on these 11 countries because of data availability and because we are primarily interested in studying fiscal integration in the Eurozone.
} 
European tax and transfer system (fully or partly) replaces the national systems. In the first scenario, we assume that the national tax and transfer systems are reduced by one third and this gap is filled by the European system. In other scenarios we look at a full substitution of the national systems and at a more progressive European system.

Regarding the economic impact of these reforms, we focus on two issues. Firstly, the distributional effects of the reform scenarios which are of key importance for the political feasibility of fiscal integration. The reforms lead to a redistribution of tax burdens between member states and across individuals, where some member states benefit and others lose. Within member states, households at different income levels can be affected very differently. We measure the redistributive effects taking into account behavioural responses in the form of labour supply adjustments (Bargain et al., 2011).

Secondly, we are interested in the impact of the different reforms on the ability of the tax and transfer system to act as an automatic stabiliser in the presence of macroeconomic shocks. This aspect is highly relevant for the debate on the role of fiscal integration for the future of the Eurozone. In particular, fiscal integration is expected to improve the resilience of the Eurozone in the event of asymmetric shocks. Building on Dolls et al. (2012), we study simulated shocks on gross income and we investigate to which extent the existence of the EU tax and transfer system contributes to macroeconomic stabilisation. We are especially interested in a scenario where individual countries are unable to let automatic stabilisers of the national tax and transfer system work because they cannot borrow. In this case the automatic stabilisers of the EU-wide tax and transfer system are of key importance.

Our analysis leads to the following results. The introduction of an EU tax and transfer system which replaces one third of the national systems would increase the disposable income of a small majority of households in Europe. At the same time it would lead to significant redistribution between countries. The winners include Greece, Portugal, Spain, Italy and, surprisingly, Germany. The average gains range between roughly 8 per cent of disposable income in Greece and one per cent in Germany. The gains in the southern European countries come at the cost, however, of a decline in labour supply. The remaining six countries, Austria, Belgium, Finland, France, Ireland and the Netherlands, lose on average. The finding that Germany benefits is surprising because, intuitively, one would expect gains and losses to be driven by differences in income levels between countries. This is true up to a certain point, but the structure of the existing tax and transfer systems plays a role as well. In France, for instance, average per capita income is lower than in Germany but the national tax and transfer system is less progressive than the German one.

Within countries, households at different income levels are affected differently. In the southern European countries, the gains are concentrated among the low income quintiles. In Germany, low and high income quintiles benefit more than the middle class. The finding that the middle income groups suffer relative to high and low income groups also holds for most other high income countries except for the Netherlands, where losses are concentrated in the high income quintiles. We also analyse the impact of the reform on income inequality within countries and EU-wide. Overall, introducing the EU tax system reduces income inequality. In most cases, this also holds for income inequality within countries. 
Overall, these findings cast doubts on the political feasibility of the reform under consideration. While a small majority of EU citizens would gain, this is not true for a majority of countries. The fact that the middle class tends to suffer in the high income countries will be another obstacle, given the widespread view that this is a politically influential group.

How does the introduction of the EU tax-benefit system affect automatic fiscal stabilisers? Unsurprisingly, the reform will increase automatic stabilisers in countries where the national tax systems have smaller stabilisers compared to the European average - this applies in particular to the southern European countries. A key question is by how much the EU tax and transfer system contributes to overall fiscal stabilisation. In the case where the EU tax and transfer system replaces one third of the national system, the EU system would absorb between 10 per cent (Portugal) and 15 per cent (Germany) of a shock to gross income. In the case of the more progressive EU tax system, the stabilisation properties change. This system would absorb between 10 per cent (Netherlands) and 29 per cent (Greece) of an income shock.

Finally, what are the implications of introducing a system of fiscal equalisation, rather than a common tax and transfer system? The fiscal equalisation system we consider is quite radical insofar as it compensates countries fully for differences between their national and the EU average taxing capacity. Accordingly, the redistributive effects are considerable. As one would expect, the system implies transfers flowing from high to low income countries.

How does this very generous system of fiscal equalisation perform when it comes to providing stabilisation in the event of an asymmetric shock? We consider a shock in the form of a decline in gross income by 5 per cent which hits Greece, Italy, Spain, Portugal and Ireland (the 'GIIPS' group). In all other countries, income remains constant. Interestingly, in terms of the stabilisation effects it offers, the fiscal equalisation mechanism performs rather poorly. In Greece, fiscal equalisation even leads to a destabilising effect. In Portugal, the stabilisation effect is close to zero. The reason is that, in the situation before the shock, Greece and Portugal are the countries which benefit most from fiscal equalisation. The shock reduces their taxing capacity, but it also reduces the taxing capacity of the union as a whole. Since other large countries like Spain and Italy and even a net contributor (Ireland) are affected, the sum of money available for fiscal equalisation declines, and countries which benefited initially may even lose transfers.

These findings have important policy implications. In order to achieve significant income stabilisation through the introduction of an EU tax and transfer system, the magnitude of this transfer system would have to be considerable. Replacing one third of the national systems by a European system would lead to stabilisers absorbing between 10 and 15 per cent of a macroeconomic shock. But establishing such a system would give rise to significant redistributive effects, which will make political acceptance difficult.

The alternative of setting up a fiscal equalisation system would potentially give rise to even larger redistributive effects, depending on the design of the system. But a high degree of fiscal equalisation does not imply that the system always offers a high degree of fiscal stabilisation in the presence of asymmetric shocks. The stabilisation effect may be different for different countries, and the example considered here shows that even a destabilising effect is possible. 
The setup of the rest of this paper is as follows. Section 2 describes the related literature and the concept and design of a fiscal union in our simulation scenarios. Section 3 introduces the empirical strategy, i.e. the micro data and the tax-benefit calculator EUROMOD, the different scenarios as well as some descriptive information. The results are presented in Section 4. Section 5 concludes.

\section{Conceptual framework and related literature}

\subsection{Related literature}

The related literature about European integration in the area of fiscal policy can be divided into two broad areas. ${ }^{3}$ The first strand of literature focuses on the EU budget, its expenditure and its revenue sources. This literature discusses issues like the size and structure of the EU budget as well as its current revenue sources (see, e.g., Atkinson, 2002; Begg, 2005). One important issue is whether the EU should be allowed to levy taxes. Currently the EU is essentially financed through contributions from the member states. Most of the literature about EU taxes focuses on indirect taxes like a European VAT or an environmental tax. Other proposals include a European corporate income tax or, more recently, a European financial transactions tax (see e.g. Le Cacheux, 2007, Begg, 2011). In this literature the key arguments in favour of a European tax are that such a tax would increase the transparency and improve democratic control of EU policies. Wigger and Wartha (2003) take a different approach and develop a theoretical model which focuses on the interaction between tax coordination and the allocation of taxing rights between the national and the EU level. They argue that, in the presence of tax coordination between member states, giving the EU the power to tax is not desirable because the coexistence of taxing powers at the national and the EU level will lead to overtaxation.

The key difference of this literature to the present paper is that none of these contributions looks at the quantitative economic effects of introducing a European tax while our focus is on the quantitative effects in terms of redistribution, labour supply, and macroeconomic stabilisation.

The second strand of literature related to the present paper is the large body of work on the implications of EMU for fiscal policy integration. An important early discussion of the key issues can be found in the MacDougall Report (1977), which had the broad objective to analyse the role of public finances for European integration. One of the key findings of the report is that "public finance in existing economic unions plays a major role in cushioning short term and cyclical fluctuations ... there is no such mechanism in place ... between member countries and this is an important reason why in present circumstances monetary union is impracticable" (p.12). This view has been confirmed by most of the later literature on the implications of EMU for fiscal

\footnotetext{
3 There is a third strand of literature which discusses the coordination and harmonisation of taxes and tariffs required to create a common market. This literature is surveyed, for instance, in Keen (1993). For the present paper this literature is less relevant because our focus is not on tax obstacles for border crossing economic activity.
} 
policy in Europe. Eichengreen (1990) compares Europe to the US and emphasises that the federal income tax in the US provides significant insurance against asymmetric macroeconomic shocks. He argues that, since regional problems are likely to be greater in Europe than in the US, fiscal shock absorbers would have to be significantly larger.

Along similar lines, many economists have warned that the Euro area is too heterogeneous and thus far away from being an optimum currency area along the lines of Mundell (1961) and Kenen (1969). Therefore, the EMU will be fragile and vulnerable to economic shocks unless it is complemented by more fiscal integration (see e.g. Sala-i-Martin and Sachs, 1992; Buiter et al., 1993; Masson, 1996; Eichengreen and Wyplosz, 1998; Engwerda et al., 2002; Uhlig, 2003). Several authors have proposed an increase in the European budget in order to establish a horizontal fiscal equalisation mechanism (Italiener and Vanheukelen, 1993; Hammond and von Hagen, 1998; Dullien and Schwarzer, 2005; Marzinotto et al., 2011). Schuknecht et al. (2011) emphasise fiscal discipline and propose an independent fiscal council for the Euro area with the aim to improve governance and compliance.

Some economists have taken the opposite view and argue that the 'unprecedented divorce between the main monetary and fiscal authorities' (Goodhart, 1998) also has advantages because it limits political influence on monetary policy (e.g. Beetsma and Bovenberg, 1998; Dixit and Lambertini, 2003; Beetsma and Giuliodori, 2010). However, the current debt crisis in the Eurozone has renewed doubts about the wisdom of this construct. Today, the view seems to prevail that a monetary union like the EMU cannot work without a major policy shift towards a fiscal union.

\subsection{What is a 'fiscal union'? Simulation scenarios}

In the debate on reforms of fiscal institutions in the Eurozone, it is not always clear what exactly the term 'fiscal union' is supposed to mean and different people use it very differently. Fuest and Peichl (2012) suggest five possible elements of a European fiscal union. These are (i) fiscal rules for the member states as well as rules concerning policy coordination and supervision, (ii) a crisis resolution mechanism, (iii) a joint guarantee for government debt, (iv) a fiscal equalisation and/or other mechanisms for transfers between countries and (v) an extended EU budget and European taxes.

While much of the current political debate focuses on short term crisis management and therefore emphasises elements (i) - (iii), the focus of this paper is on elements (iv) and (v), which are more relevant in the long term.

Of course, a significant shift of policy responsibilities to the European level raises many questions in terms of construction and how the central budget is used. More precisely, one key question is how the fiscal equalisation mechanism combined with a European income tax will function. In order to choose scenarios for the type of a fiscal union we are going to model, we distinguish three dimensions which serve as a framework for the specific design of a European tax-benefit system: (1) overall revenue, (2) the design of the EU tax and transfer system and its share in overall taxes and transfers and (3) the assignment of revenues and the existence of a fiscal equalisation mechanism. 
First, for overall revenue, we assume our reforms to be revenue neutral at the EU level. This choice appears to be a natural solution for two reasons. First, it ensures the comparability of different scenarios. Second, by keeping the overall budget constant, we avoid the debate about increasing (decreasing) the size of government. This, however, does not imply revenue neutrality at the national level, as will be discussed further below.

Second, for the design of the EU tax-benefit system, several approaches are possible in principle. The system could be designed from scratch. A simple way of doing so would be to introduce an EU tax surcharge, where the surcharge could simply be a percentage of national income tax payments. But this approach raises various difficulties. Most importantly, since national income tax systems differ widely across member states, such a system would benefit countries with low income taxes, and it would create incentives for individual member states to rely more on revenue sources other than income taxes like e.g. social insurance contributions or replace transfers by tax credits which reduce income taxation.

Therefore, we consider the introduction of a separate tax and transfer system which would partly or fully replace the national systems. What we will use here is an 'average system' which leads to the same revenue and progressivity at the EU level as a combination of the existing national systems. At least with view to progressivity, this is an arbitrary choice even when conditioning on revenue neutrality. Thus, we will also consider a scenario that increases progressivity of the overall system, while again ensuring that overall revenue remains constant.

Regarding the share of the EU system in overall taxes and transfers, a wide range of scenarios could be considered. At one extreme, we could assume that the EU tax-benefit system completely replaces national systems. However, in most existing fiscal unions, there are tax-benefit systems at different levels of government. For instance, in the US, two thirds of overall tax revenue are collected at the federal level versus one third at the state and local level. However, moving two thirds of the national tax and transfer systems to the EU level seems implausible. In our analysis, we will therefore look at two scenarios: in the first scenario the EU system replaces one third of the national systems; in the second scenario, the national systems are replaced entirely. Clearly, the latter scenario is more relevant as a theoretical benchmark whereas the former might be something that might happen if the EU decides to move to a federal fiscal system.

Third, we have to make assumptions regarding the assignment of tax revenues and the existence of a fiscal equalisation mechanism. We do this as follows. In our simulations of the introduction of a European tax and transfer system, we assume that any net revenues (revenues after taxes and transfers) generated by the EU system will be pooled, and each country will receive a transfer from this pool which is equal to the initial net revenue collected under the national tax systems. This assumption implies that redistribution between countries in our simulations is driven by the fact that the EU average system changes the net tax burdens of households. We hold constant the net tax revenue each member state receives, so that the provision of public goods is kept constant in all countries. An alternative assumption would be to assume that net tax revenues are redistributed as well.

This issue will be discussed in the simulations about fiscal equalisation. For this purpose we will assume that member states keep their tax and transfer systems but the EU tax and transfer 
system will be used as an indicator of taxing capacity. Member states with a taxing capacity below the EU average will be recipients in the fiscal equalisation mechanism and vice versa. We will then investigate to which extent $i$ ) the fiscal equalisation mechanism redistributes income between member states compared to a situation without equalisation and ii) the fiscal equalisation mechanism cushions the impact of an asymmetric economic shock.

\subsection{Conceptual framework}

In this section we describe the income concept used in our simulations and illustrate the idea of constructing an average tax system with a simple example. How we estimate the specific average tax system given our data is explained in section 3.2. Our simulations proceed as follows. We start with representative household micro data from each of the $11 \mathrm{EU}$ member states which enter our simulations. Market income $X_{i}$ of individual $i$ is defined as the sum of all incomes from market activities:

$$
X_{i}=E_{i}+Q_{i}+I_{i}+P_{i}+O_{i}
$$

where $E_{i}$ is labour income, $Q_{i}$ business income, $I_{i}$ capital income, $P_{i}$ property income, and $O_{i}$ other income. Disposable income $Y_{i}$ is defined as market income minus net government intervention $G_{i}=T A X_{i}+S I C_{i}-B E N_{i}$ :

$$
Y_{i}=X_{i}-G_{i}=X_{i}-\left(T A X_{i}+S I C_{i}-B E N_{i}\right),
$$

where $T A X_{i}$ are direct taxes, $S I C_{i}$ employee social insurance contributions, and $B E N_{i}$ are social cash benefits (i.e. negative taxes). Note that, due to a lack of microdata, we cannot include indirect taxes and in-kind benefits in our analysis.

For an illustrative example of a common tax and transfer system, assume two countries $A$ and $B$ with individual tax schedules $T_{i}=f_{i}\left(X_{i} \mathbf{z}_{i}\right)$. To keep the example as simple as possible, consider a linear progressive tax schedule independent of characteristics $\mathbf{z}_{i}$, i.e. $T_{i}=f_{i}\left(X_{i} \mathbf{z}_{i}\right)=t_{i} X_{i}-a_{i}$ with $t_{i}$ the marginal tax rate and $a_{i}$ a refundable tax credit (equal to a benefit if $t_{i}$ is negative). A simple way to introduce a revenue neutral common tax system is to use the average system

$$
T^{A v g}=\frac{t_{A} X_{i}-a_{A}+t_{B} X_{i}-a_{B}}{2}=\frac{t_{A}+t_{B}}{2} X_{i}-\frac{a_{A}+a_{B}}{2} .
$$

In reality, tax-benefit systems do not only depend on income but on other characteristics, too. In addition, the observed tax-benefit systems are directly progressive. We therefore construct the EU average tax and transfer system using a regression approach as described in section 3.2, but the economic intuition is as in our simple example.

\section{Empirical strategy}

\subsection{EUROMOD: model and database}

As we do not observe data on what would have happened if we introduced an EU-wide taxbenefit system, we need to run counterfactual simulations. We use the microsimulation technique to calculate taxes, benefits and disposable income under different scenarios for a representative micro-data sample of households. Simulation analysis allows conducting a 
controlled experiment by changing the parameters of interest while holding everything else constant. Therefore, the researcher does not have to deal with endogeneity problems when identifying the effects of the policy reform under consideration.

Simulations are carried out using EUROMOD, a static tax-benefit model for the EU countries, which was designed for comparative analysis. Through a common framework, which has a greater flexibility than typical national models to accommodate a range of different tax-benefit systems, it allows the comparison of countries in a consistent way. EUROMOD was originally created in the late 1990s, by a consortium of research institutions from each EU15 country with a good knowledge and expertise in their respective national tax-benefit systems, and has been regularly updated since then. The tax-benefit systems included in the model have been validated against aggregated administrative statistics as well as national tax-benefit models (where available), and the robustness checked through numerous applications (see, e.g., Bargain, 2007).

The model can simulate most direct taxes and benefits except those based on previous contributions as this information is usually not available from the cross-sectional survey data used as input datasets. Information on these instruments is taken directly from the original data sources (if available). EUROMOD assumes full benefit take-up and tax compliance, focusing on the intended effects of tax-benefit systems.

The main stages of the simulations are the following. First, a micro-data sample and tax-benefit rules are read into the model. Then for each tax and benefit instrument, the model constructs corresponding assessment units, ascertains which are eligible for that instrument and determines the amount of benefit or tax liability for each member of the unit. Finally, after all taxes and benefits are simulated, disposable income is calculated. This simulated disposable income includes all monetary incomes, except capital gains and irregular incomes. ${ }^{4}$

Our analysis is based on the 2001 tax-benefit systems, two years after the introduction of the Euro for the EURO-12 countries. The input datasets for these countries are summarised in Table C.1 in the Appendix. The sample sizes vary across countries from 7,000 to more than 25,000 households. All monetary variables are updated to the 2001 year using country-specific uprating factors, as the income reference period varies from 1999 to 2001.

\subsection{Scenarios}

In this section we explain in a more technical manner how we conduct the simulations of the different reform scenarios introduced in Section 2.2. We proceed in four steps.

1. We use EUROMOD, which contains an exact representation of the (direct) tax-benefit systems of the Eurozone countries in 2001, to extract detailed individual budget curves for each household $i$ in representative samples for each country $c$. In particular, EUROMOD simulates the country specific net taxes (income and payroll taxes minus

\footnotetext{
${ }^{4}$ For further information on EUROMOD, see Sutherland (2007). There are also country reports available with detailed information on the modelling and validation of each tax benefit system, see http://www.iser.essex.ac.uk/research/euromod.
} 
benefits) $T_{i c}=f_{c}\left(X_{i}, \mathbf{z}_{i}\right)$ as a function of gross income $X_{i}$ and a vector of non-income factors $\mathbf{z}_{i}$ (e.g. marital status, number and age of children) taken from the data.

2. Using the simulated net tax schedule $T_{i c}$ for all European citizens, we obtain the average EU tax function $T_{i, \text { EUavg }}$ such that it yields the same net revenue at the EU level as the sum of the national systems. In order to calculate this average system, we estimate the following reduced form tax function on the pooled sample:

$$
T_{i}=\omega_{i} f_{E U}\left(X_{i}, \mathbf{z}_{i}\right)+\varepsilon_{i} .
$$

Function $f_{E U}$ is specified as a flexible transformation of $\left(X_{i}, \mathrm{z}_{i}\right) \rightarrow T_{i c} \cdot \varepsilon$ is the OLS residual and $\omega_{i}$ the household sample weight. Given that weights sum up to the EU population size, this function directly accounts for a population weighted average tax function at the EU level. The fit of this tax regression in terms of the R2-measure is close to 1 . It is not equal to 1 , though, because by regressing on the pooled sample, differences across countries will be explicitly captured.

3. The estimated function is then used to predict net tax payments for the EU average tax system $T_{i, \text { EUavg }}$ for each household in the sample.

4. Next, we use the predicted EU average tax system to construct four different scenarios of replacing the national tax-benefit systems with an EU-wide system (again, yielding the same revenue on the EU-level, but not within countries). In each of the four scenarios the EU-wide system is a weighted combination of the current national system $T_{\text {nat }}$ and the EU average system $T_{E \text { Eavg }}$. The first two scenarios are chosen such that the share of the average system is $33.3 \%$ (partial integration) and $100 \%$ (full integration). The benchmark is the current national system of each country (i.e. the share of the average system is $0 \%$ ). Formally, we calculate for each household $i$ of country $c$

$$
T_{i}=w T_{i, E \text { Uavg }}+(1-w) T_{i c} ; w \in\left\{\frac{1}{3}, 1\right\} \cdot 5
$$

In the third and the fourth scenario the share of the average system will be equivalent to scenarios one and two, however, the progressivity of $T_{i, \text { EUavg }}$ will be increased, leading to $T_{i, \text { UUavg_}_{-}}$(again yielding revenue neutrality). ${ }^{6}$

${ }^{5}$ For $w=\frac{2}{3}$, results are qualitatively similar and lie in between the results for $w=\frac{1}{3}$ and $w=1$. We thus do not report these results due to lack of space.

6 Precisely, we calculate $T_{\text {EUavg }}$ by first introducing a proportional surcharge of $7.5 \%$ to $T_{\text {EUavg }}$ which subsequently will be fully redistributed across all households in the pooled sample via a lump sum transfer equal to its $\operatorname{mean}_{N}$ value across households, i.e. $T_{i, \text { EUavg } p}=T_{i, \text { EUavg }}+T_{i, \text { EUavg }} * 0.075-b \quad$ with $b=\frac{1}{N} \sum_{i=1}^{N} T_{i, \text { EUavg }} * 0.075$. Results for a surcharge of 5\% (10\%) are qualitatively in line with the results presented here and $i=1$ imply less (more) pronounced with view to the expected effects when increasing progressivity for the EU average system (detailed results available upon request). 
Subsequently, the four scenarios are labelled EUavg-Sc. 1, Sc. 2 and EUavg_p-Sc. 1, Sc. 2. Figure 1 plots the current national tax-benefit function as well as the two EU average functions. While the EU average function is, by construction, basically identical to the average of the national systems, the increased progressivity for the second function becomes visible especially at the top of the distribution.

Fig. 1: EU average tax-benefit schemes and average of national systems

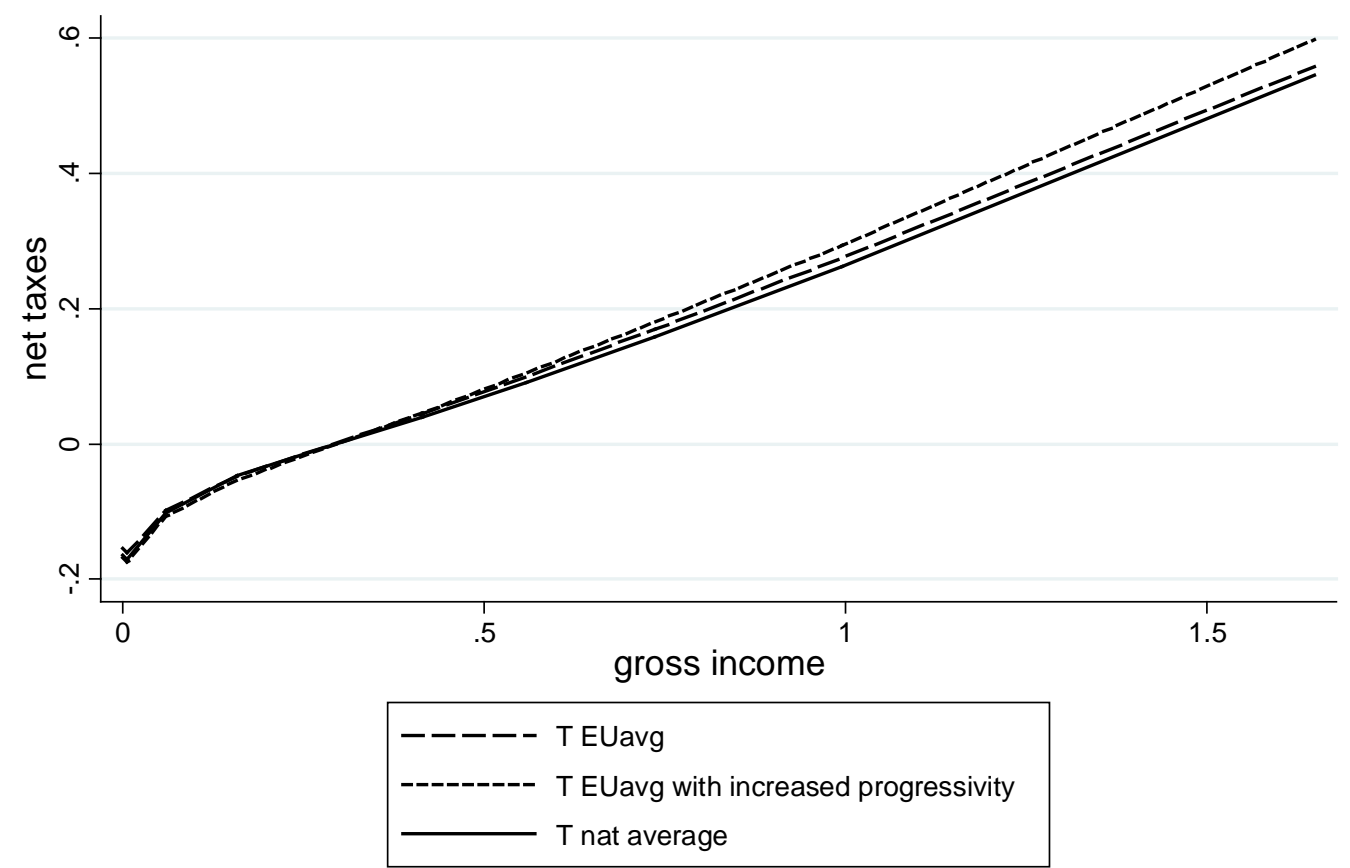

Note: Based on overall means for gross income deciles; weekly thousand 2001 EUR. Source: Own calculations based on EUROMOD.

What are the implications of these scenarios for redistribution between countries? By construction, we assume that all of the revenue collected from $T_{\text {EUavg }}$ as well as $T_{\text {EUavg_p }}$ goes to the central EU budget and is immediately redistributed across countries and households (note that the tax function based on the pooled sample predicts household net tax payments as a fraction of the central budget, not as a fraction of national budgets). The structure of national budgets is affected in the sense that it is reduced according to the weighting factor $(1-w)$. In the extreme scenario with $w=1$ it is decreased to zero. As explained in section 2.2, we assume that net revenues (revenues after transfers) collected by the newly introduced EU system are always redistributed to the member states to compensate them, so that their expenditure out of the transfer system is unaffected. We also assume that revenues and expenditures which are not captured by our data like revenues from indirect or corporate income taxes or expenditures on defence and other publicly provided goods remain constant at the national level. 
Fig. 2: National tax-benefit schemes compared to EU average systems

AT

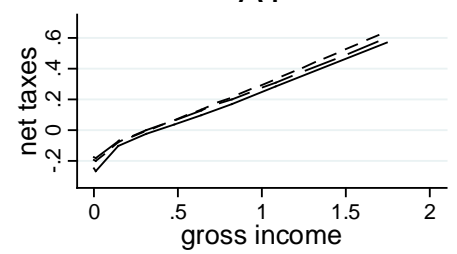

FR

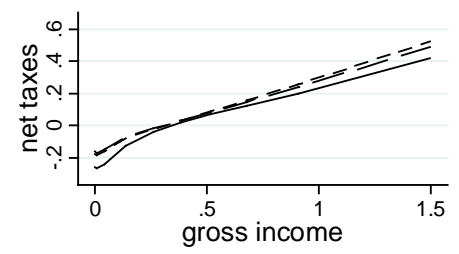

IR

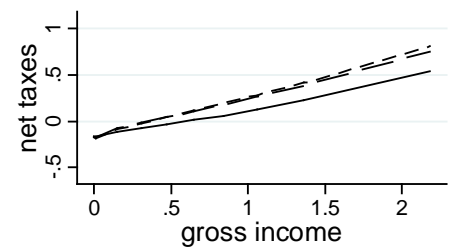

PT

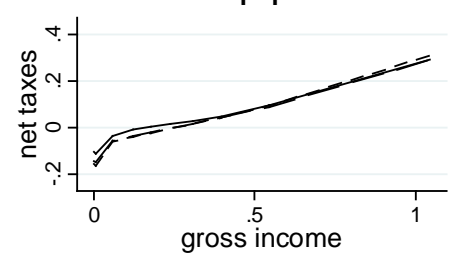

BE

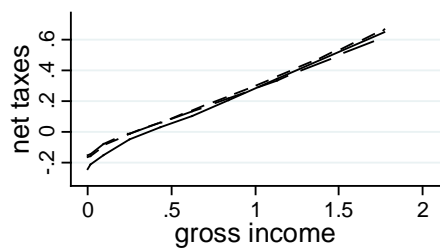

GE

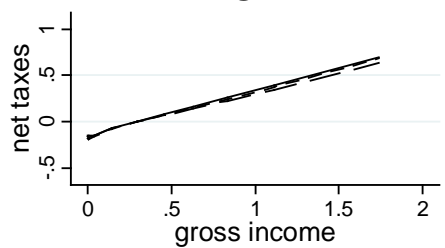

IT

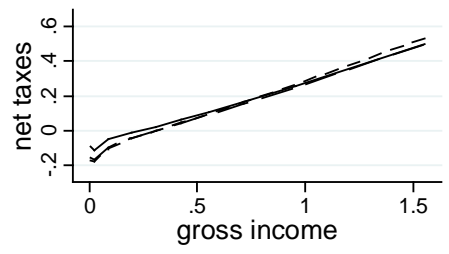

SP

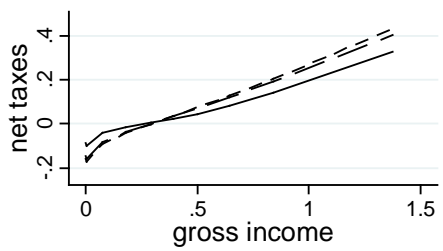

FI

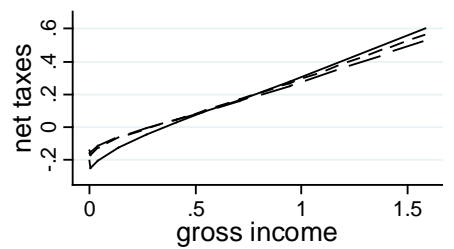

GR

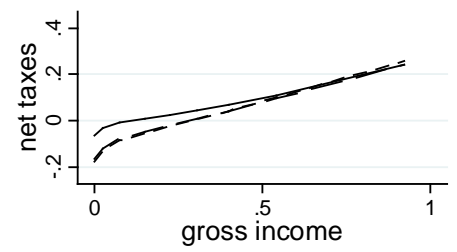

NL

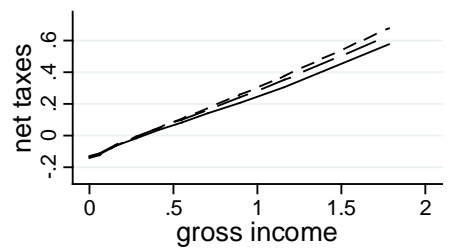

\section{T nat}

\section{T EUavg}

\section{T EUavg with increased progressivity}

Note: Based on country means for gross income deciles; weekly thousand 2001 EUR.

Source: Own calculations based on EUROMOD.

Figure 2 includes plots of the current national tax-benefit functions as well as the two EU average functions for each country in the sample. It is immediately evident that the redistributive effects of the different reforms under consideration will differ between countries. In some cases the EU average function is always below (above) the national tax-benefit system and sometimes there are crossings. Hence, different parts of the income distributions will be affected differently. A first visual inspection suggests that low income households in Greece as well as high income households in Finland and Germany will gain, while especially high income households in France, Ireland and Spain will pay higher taxes. 


\subsection{Descriptive information}

In this section we report descriptive information on the variables used in our simulation exercise as well as for the estimated tax reform scenarios. We report values of these variables at the overall EU level as well as for individual countries (population share in the first column of Table 1).

Tab. 1: Weekly household gross and disposable income, benefits, SIC and taxes (2001 EUR)

\begin{tabular}{lccccccccc}
\hline \hline & $\begin{array}{c}\text { Pop. } \\
\text { share }\end{array}$ & $\begin{array}{c}\text { Gross } \\
\text { income }\end{array}$ & $\begin{array}{c}\text { Disp. } \\
\text { income }\end{array}$ & $\begin{array}{c}\text { Gross } \\
\text { taxes } \\
\text { baseline }\end{array}$ & $\begin{array}{c}\text { Gross } \\
\text { SIC } \\
\text { baseline }\end{array}$ & $\begin{array}{c}\text { Gross } \\
\text { benefits } \\
\text { baseline }\end{array}$ & $\begin{array}{c}\text { Net } \\
\text { taxes } \\
\text { baseline }\end{array}$ & $\begin{array}{c}\text { Net } \\
\text { taxes } \\
\text { EUavg }\end{array}$ & $\begin{array}{c}\text { Net } \\
\text { taxes }\end{array}$ \\
\hline EU & 1.00 & 492.6 & 466.4 & 86.6 & 67.5 & 127.8 & 26.3 & 26.3 & 26.3 \\
AT & 0.03 & 544.3 & 543.0 & 104.0 & 94.1 & 193.6 & 1.3 & 44.0 & 45.3 \\
BE & 0.04 & 547.2 & 503.5 & 146.1 & 54.0 & 155.1 & 43.7 & 53.4 & 55.5 \\
FI & 0.02 & 507.9 & 464.9 & 159.3 & 35.0 & 150.8 & 43.0 & 46.2 & 47.6 \\
FR & 0.21 & 463.7 & 487.6 & 42.9 & 89.1 & 155.6 & -23.8 & 17.8 & 17.1 \\
GE & 0.32 & 519.5 & 457.7 & 100.3 & 86.8 & 124.9 & 61.8 & 49.3 & 51.0 \\
GR & 0.03 & 259.4 & 254.5 & 25.4 & 34.4 & 54.7 & 4.9 & -60.1 & -66.5 \\
IR & 0.01 & 699.8 & 662.5 & 116.3 & 25.8 & 104.3 & 37.3 & 93.7 & 98.7 \\
IT & 0.17 & 498.4 & 484.4 & 104.6 & 40.6 & 131.8 & 14.0 & 2.4 & 0.6 \\
NL & 0.06 & 614.6 & 537.9 & 75.5 & 106.2 & 104.1 & 76.6 & 86.5 & 91.1 \\
PT & 0.03 & 314.2 & 308.4 & 35.4 & 31.6 & 61.7 & 5.8 & -37.5 & -42.3 \\
SP & 0.10 & 430.9 & 436.1 & 68.0 & 26.1 & 97.6 & -5.2 & -14.8 & -17.9 \\
\hline \hline
\end{tabular}

Note: EUavg indicates the EU average tax system, EUavg_p the same system with increased progressivity. Source: Own calculations based on EUROMOD.

Columns 2 and 3 in Table 1 show the average weekly gross and disposable incomes per household, respectively. Columns 4 to 6 include initial gross taxes, employee social insurance contributions (SIC) and benefits. Column 7 reports initial net taxes, that is income taxes plus SIC paid minus cash benefits received. In France and Spain average net taxes are negative. This reflects that benefits paid by the government exceed revenue from income taxes and SIC. These countries need other revenue sources like, for instance, indirect taxes to finance transfers. The last two columns of Table 1 report net taxes that emerge under the EU average system (without and with increased progressivity in columns 8 and 9, respectively). Note that, at the EU level, both systems lead to the same average net tax revenue as the sum of the national systems in the baseline.

Figure 3 illustrates how gross income is transformed into disposable income through the effects of income taxes, social insurance contributions and transfers. This figure shows that the structures of tax and transfer systems differ considerably across member states. For instance, in France income taxes play a relatively small role in financing transfers, i.e. SIC and other revenue 
sources, which are not included in our analysis, play a much more significant role than in countries like Germany or Belgium.

Fig. 3: Composition of 100 Euros disposable income by country

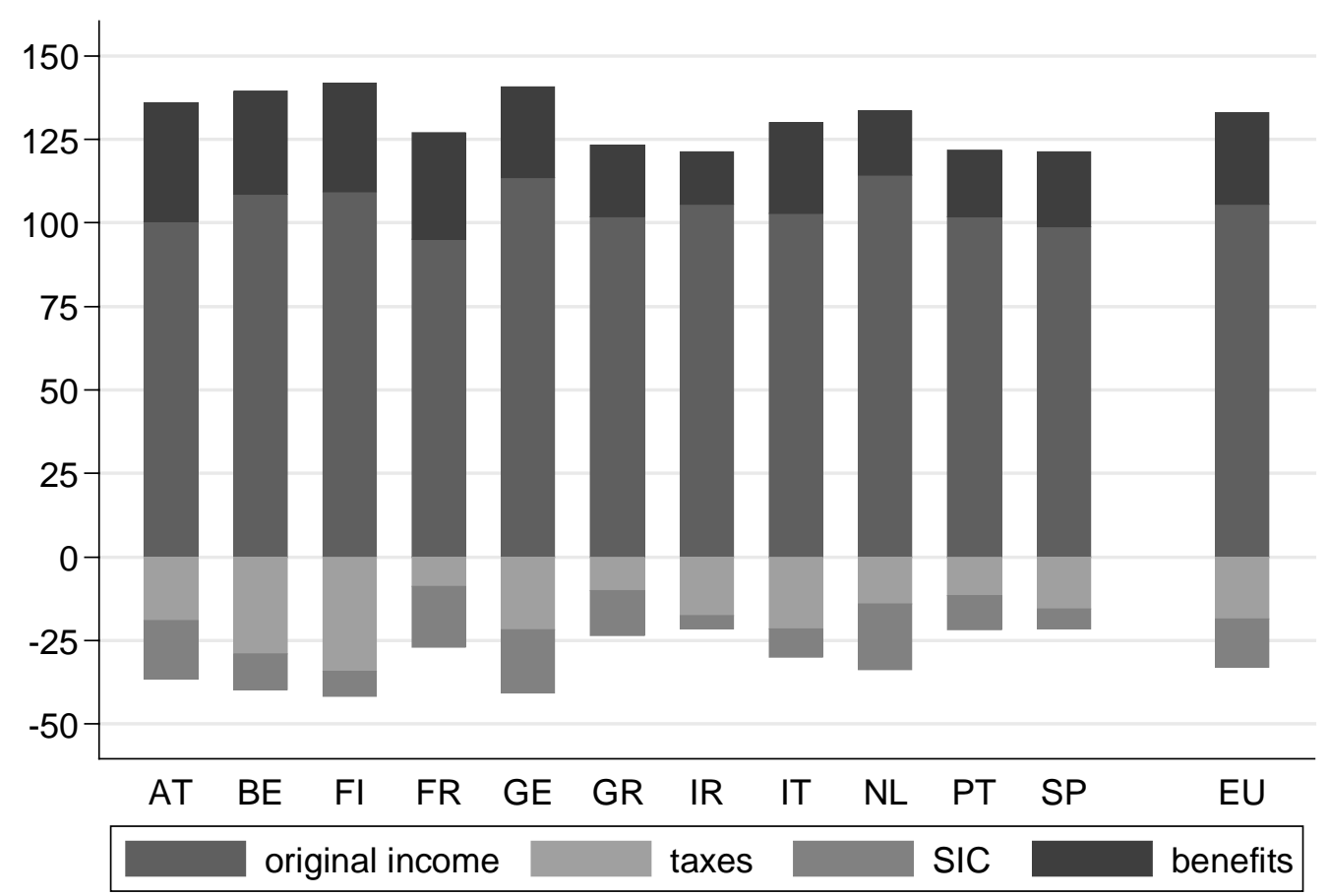

Source: Own calculations based on EUROMOD.

Table 1 and Figure 3 reveal that there are considerable differences across individual countries with respect to both income levels and the structure of the tax-benefit level. Average gross income ranges from almost 700 Euros in Ireland, which is 42 per cent above the EU average of 493 Euros, to a value of 259 Euros in Greece, just 52 per cent of the EU average. One should note, however, that these income levels are not adjusted for differences in purchasing power. If differences in purchasing power are taken into account, income differentials are somewhat smaller ${ }^{7}$. Initial net taxes also differ considerably, between 77 Euros in the Netherlands and -24 Euros in France. Under a common tax system, the EU average system, net taxes would change significantly. In the Netherlands they would increase to 87 Euros while the countries with the largest net transfers would now be Greece ( -60 Euros) and Portugal (-38 Euros). This is plausible because these countries have the lowest gross income levels. In the EU average system with higher progression these effects are reinforced, as one would expect.

\footnotetext{
${ }^{7}$ This leads to slight changes when recalculating the results presented in section 4 for PPP-EUR. The main difference is that Spain now shows a majority of gainer households for the reforms considered while the rest of the findings is qualitatively broadly in line with the results presented here, i.e. for not PPP-adjusted 2001 EUR (detailed results available upon request).
} 


\section{Results: Economic effects of a 'fiscal union'}

In this section we present and discuss the key results of our simulated policy scenarios. The results are presented in three subsections. Section 4.1 focuses on the impact of introducing the common EU tax system on the distribution of income. We consider the four scenarios described in the previous section (share of the EU average system of $33.3 \%$ and $100 \%$, respectively, with and without increased progressivity). The distributive effects are analysed in two steps. First, we consider changes in disposable income. Second, we look at changes in inequality and a measure of welfare which takes into account inequality as a welfare reducing factor. For instance, a country with significant income redistribution in its national system might not find a reform which increases average disposable income of its households beneficial if this comes at the cost of an increase in inequality. In this section we are also interested in whether a majority of voters benefits or loses because this may affect political feasibility. Subsequently, changes for income quintiles in the different countries are considered. Throughout the analysis, behavioural effects in the form of labour supply adjustments are accounted for. In the Appendix we summarise these effects (Table B.1), and we also report results without behavioural adjustments.

Section 4.2 investigates the potential of the EU average tax system to act as an automatic fiscal stabiliser in presence of an asymmetric shock, compared to that of the current national taxbenefit systems. While by construction, fiscal stabilisation is provided as a sum of national and EU average stabilisation (in the scenarios where the EU system does not take over 100\%), we also look at the sole stabilisation effect of the EU average system. This is relevant in cases where countries are credit constrained at the capital market, as is currently the case for some countries in the Eurozone.

Finally, Section 4.3 turns to the issue of fiscal equalisation. There we propose a system of fiscal equalisation which is based on differences in taxing capacity across countries. We calculate transfers between countries that would be generated by this type of system and we consider a scenario where a subset of countries - the GIIPS group - is affected by a negative macroeconomic shock. We then calculate to which extent a fiscal equalisation mechanism would provide insurance against this type of shock.

\subsection{Introducing an EU tax and transfer system: Changes in disposable income, inequality and welfare}

How does the introduction of the common tax and transfer system redistribute income between households in Europe? Table 2 summarises information on changes in disposable income for all four scenarios. The first column for each scenario simply reports the fraction of winners in terms of changes in disposable income - for the EU as a whole as well as for each country. While this information does not account for the size of gains or losses (an increase in disposable income by one cent already constitutes a winner), the average size is given in the second column for each scenario. Even if a country shows a majority of winners (losers) it might be the case that the average gain (loss) of the winners (losers) is lower than the average loss (gain) of the losers (winners). This additional information is summarised in the last two columns for each scenario. As can be seen from Table 2, a partial introduction of the EU average system leads to a slight majority of winners at the EU level. The share of winners increases slightly when moving to full 
integration. Note that, by construction, the shares of losers and winners do not change over these two scenarios in case of fixed labour supply. Therefore the change in the fraction of winners/losers can only be due to behavioural responses. In sum, a switch to a (partly) integrated EU average income tax system leads to a slight majority of winners in terms of the net tax burden on the EU level, i.e. such a reform would be feasible from a majority voting perspective (while weekly disposable income on average slightly decreases and the average loss is higher than the average gain for the first scenario).

However, at the level of the individual member states, a majority of winners is only given in 5 out of 11 countries, namely Greece, Italy, Portugal, Spain and, perhaps surprisingly, Germany. In Spain and Germany, average gains in disposable income are rather small. As one would expect the gains in terms of disposable income are largest in Greece, on average more than 8 per cent, and Portugal (4.5 per cent). One should note, however, that this benefit comes at a cost in terms of labour supply, which falls in all winner countries except Germany (see Table B.1 in the Appendix). In Greece and Spain labour supply falls, measured in full time equivalents, by more than 2 per cent. The most significant income losses occur in Austria, Ireland and France, where average disposable incomes decline by between 2 and 3 per cent. Here, the labour supply effects are mostly positive, except for Ireland and the Netherlands, where labour supply declines slightly.

An interesting aspect of this result is that intuitively, one would assume that the rich countries systematically lose in a common system. This is only partly true. Although average gross incomes in Finland and France are lower than in Germany, the former two countries lose while Germany benefits. It is particularly puzzling that Germany and France are affected very differently, with France losing significantly although its average income is lower. The explanation for this finding is that the national tax and transfer systems of these two countries are very different, despite their similarity in other dimensions. Inspecting Figure 2 shows that, indeed, the EU tax system implies higher taxes and lower transfers than the French national system. This implies that the net tax burden on the French population increases. In addition, French income levels are close to the EU average, so that the country cannot hope to benefit from participating in a system with higher average incomes. As Figure 5 shows, the losses in France are distributed rather evenly across income groups, with the third and fourth quintiles suffering slightly more than the high and low income quintiles. In Germany, however, the situation is different. The national tax and transfer system is characterised by higher progressivity and slightly higher taxes for high income earners. For lower income levels, the distance between the national and the EU tax and transfer systems is rather small. As a result all quintiles in Germany gain from the introduction of the EU tax.

The general pattern of results in terms of losers and winners at the country level is robust when switching to the EU average tax system with an increase in tax progression. The numbers of winners and losers change slightly, as do the magnitudes of average gains and losses. But no country shows a shift from a majority of losers to a majority of winners or vice versa. 
Tab. 2: \% gainers, overall \%-change, mean gain and loss in weekly disposable income (2001 EUR)

\begin{tabular}{|c|c|c|c|c|c|c|c|c|c|c|c|c|c|c|c|c|}
\hline & \multicolumn{4}{|c|}{ EUavg-Sc. 1} & \multicolumn{4}{|c|}{ EUavg-Sc. 2} & \multicolumn{4}{|c|}{ EUavg_p $_{-}-S c .1$} & \multicolumn{4}{|c|}{ EUavg_p -Sc. 2} \\
\hline & $\%+$ & $\% d Y$ & Gap+ & Gap- & $\%+$ & $\% d Y$ & Gap+ & Gap- & $\%+$ & $\% d Y$ & ap+ & Gap- & $\%+$ & $\% d Y$ & Gap+ & Gap- \\
\hline EU & 52 & & & 4 & 53 & & & & 1 & -0.1 & & 1 & 53 & & & 19.4 \\
\hline H & $2 T$ & & 10.0 & 20.5 & 20 & 1.1 & 47.2 & -07.4 & 24 & -2.0 & & $-2 J .0$ & $2 J$ & 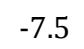 & 45.8 & -67.8 \\
\hline $\mathrm{BE}$ & 7 & -1.0 & 19.1 & -19.2 & 12 & 0 & 5 & 5 & 4 & 1 & 18.2 & 0 & 38 & -1.6 & 6 & 181 \\
\hline $\mathrm{Fl}$ & 47 & 0 & 1 & -12.2 & 49 & 0.7 & 4 & -35.8 & 45 & -0.1 & $1:$ & -12.0 & 47 & 0.1 & 0 & -35.1 \\
\hline FR & 14 & -2.8 & 8 & -17.2 & 15 & -8.0 & 22.9 & -50.9 & 15 & -2.7 & & -17.4 & 16 & -7.9 & 23.3 & -51.2 \\
\hline $\mathrm{GE}$ & 71 & 1.1 & & -14.0 & 72 & 3 & & -42.4 & 9 & 0.9 & & -13.0 & 70 & 2.9 & 5.3 & -39.1 \\
\hline GR & 82 & 8.2 & . & -10.0 & 83 & 25.1 & 84.3 & -30.0 & 81 & 9.0 & & 1 & 82 & 27.8 & & -33.9 \\
\hline If & 27 & -2.9 & 20.7 & 1. & 20 & 8 & 6 & 1005 & 27 & 21 & & 2 & 28 & 80 & 76.3 & 11 \\
\hline IT & 64 & 0.8 & 12.7 & -12.4 & 65 & 2.6 & 38.9 & -37.2 & 65 & 0.9 & 11.1 & -14.6 & 66 & 3.0 & 45.0 & -43.8 \\
\hline NL & 35 & -0.6 & 15.7 & -13.7 & 35 & -1.6 & 47.2 & -39.7 & 35 & -1.0 & 18.7 & -18.5 & 36 & -2.6 & 55.6 & -53.3 \\
\hline $\mathrm{P} 7$ & 69 & 4.5 & 26.9 & -13.8 & 69 & 13.7 & 80.5 & -40.8 & 6 & 4.9 & 30 & -15.3 & 68 & 15.1 & 91.8 & -44.7 \\
\hline SP & 58 & 0.2 & 16.4 & -20.1 & 62 & 2.6 & 50.1 & -50.1 & 59 & 0.5 & 19.2 & -22.4 & 63 & 3.4 & 58.0 & -56.8 \\
\hline
\end{tabular}

Note: $\%+$ is the percentage of reform gainers (100 minus $\%+$ is the percentage of reform losers); $\% d Y$ the overall \%-change in household weekly mean disposable income; Gap+ (Gap-) the mean difference from zero for positive (negative) dY. Source: Own calculations based on EUROMOD.

While some countries gain (lose) in terms of income, it might be the case that they simultaneously lose (gain) in terms of inequality and welfare. Thus, changes in disposable income might not be the only relevant indicator to policy makers for such a reform. Therefore, Table 3 additionally reports the Gini coefficient across countries as well as its percentage change due to the introduction of the different scenarios. Next, this information is integrated with the change in disposable income into a social welfare function (SWF) of the Yitzhaki type (Yitzhaki, 1979), i.e. $W=\mu^{*}(1-G)$ with $\mu$ the mean disposable income of the respective population and $G$ the accordant Gini index.

Table 3 reveals that, at least in the first two scenarios, the pattern of winner and loser countries does not change when looking at welfare instead of disposable income, i.e. it is again the same group of countries - Germany, Greece, Italy, Portugal and Spain - that benefits in terms of the percentage change in social welfare as measured by $W$. Inequality also declines in the EU as a whole, as well as in all individual countries except Austria, Belgium, Finland and France which already have low levels of inequality in the baseline. Greece is again the country that benefits most, showing the largest decrease in the Gini coefficient (having the highest level of initial inequality). When moving to the average system with increased progressivity, the overall pattern again does not change. However, as can be expected, decreases (increases) in inequality (increases (decreases) in welfare) become stronger (less strong or even negative) compared to the scenarios without increased progressivity. 
Tab. 3: Gini-Index (G, \%-changes $d G)$ and Welfare (W, \%-changes dW)

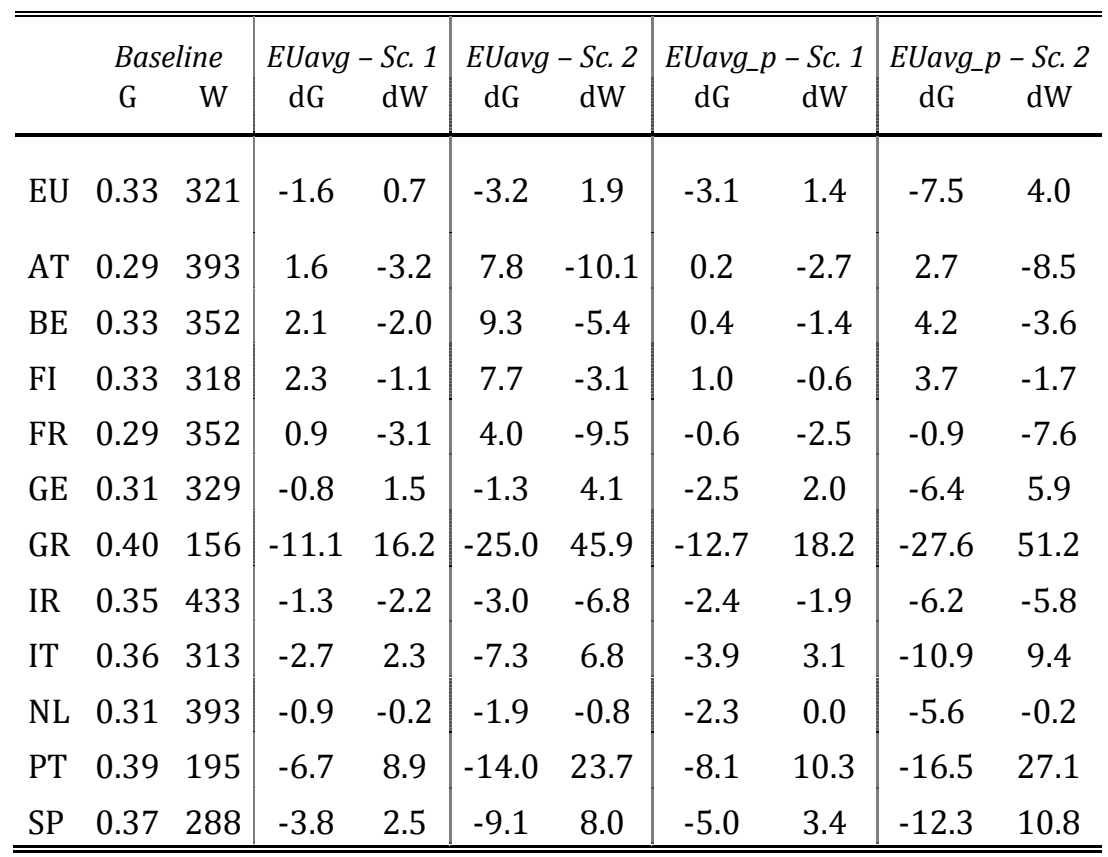

Source: Own calculations based on EUROMOD.

While overall and country level changes in income are the most important indicators for answering the question whether political support for (partly) introducing an EU tax-benefit system can be expected, policy makers might be additionally interested in which income groups within countries particularly benefit or lose. Figure 4 shows the share of winners within gross income quintiles of the overall sample population by scenario. The effects of all four scenarios are rather similar for the overall EU income distribution: the bottom quintiles gain on average in each scenario while the top quintiles lose. The effect of increased progressivity becomes visible as well: the share of winners increases with higher progressivity for quintiles 1 and 2 while for the fourth and the fifth quintile, it is the share of losers that increases.

Fig. 4: Share of winners in global quintiles by reform scenario

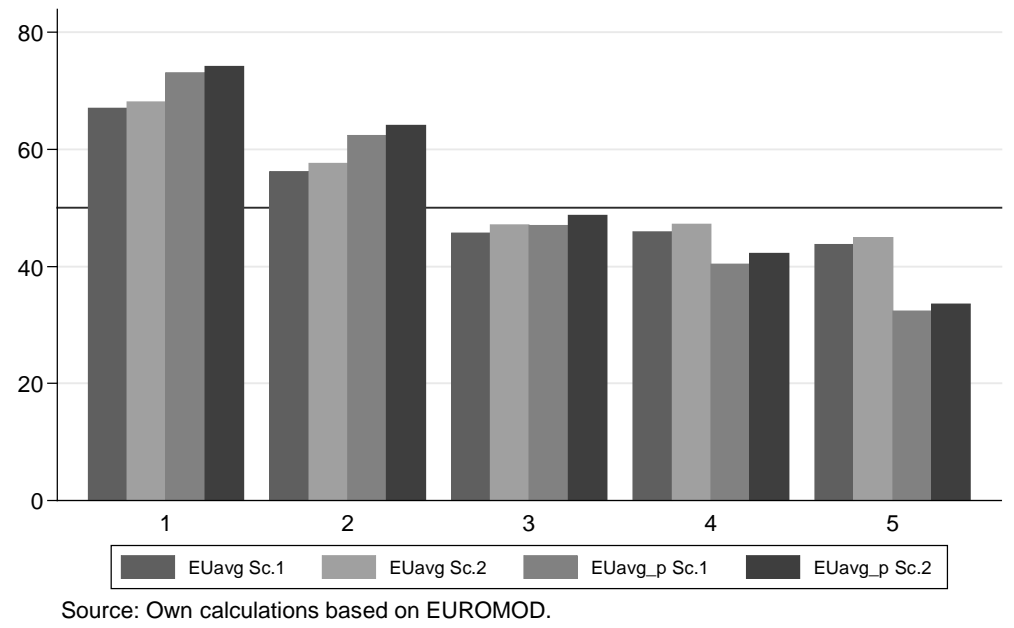


This can be compared to the share of winners within gross income quintiles for the different scenarios by countries in Figure 5. The left (right) panel displays the 6 (5) countries which on average suffer (benefit) from the EU tax reform. Consider first the countries which benefit on average. In the four southern European countries, low income quintiles benefit most because the transfers in the EU system are more generous than the transfers in the national systems. In Italy and Spain high income quintiles mostly lose. In Germany, the pattern is different. The share of winners is higher in the upper and lower quintiles and slightly lower in the middle class. This pattern - a higher share of losers in the middle income quintiles - can also be observed in several of the 'loser' countries, such as Austria, Belgium and France. In Ireland and the Netherlands, the losses mostly fall on the high income quintiles.

Fig. 5: Share of winners in country quintiles by scenario

\section{EUavg Sc.1}
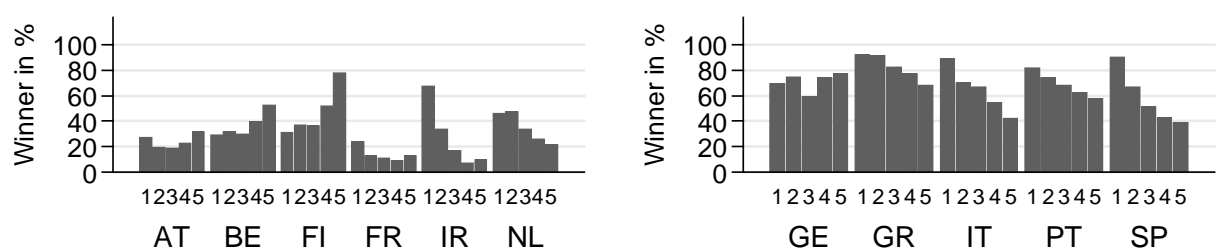

EUavg Sc.2
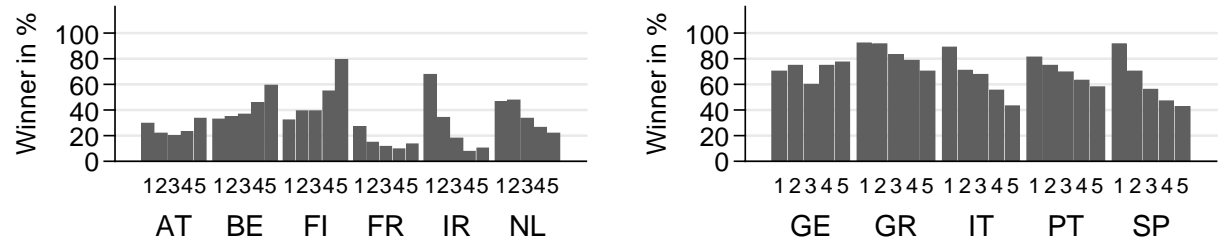

EUavg_p Sc.1
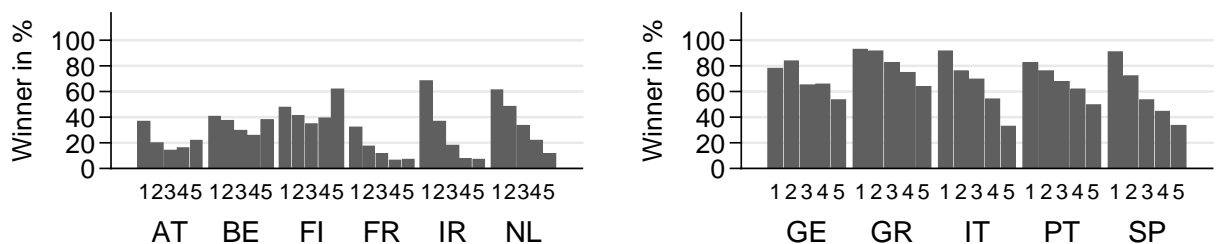

EUavg_p Sc.2
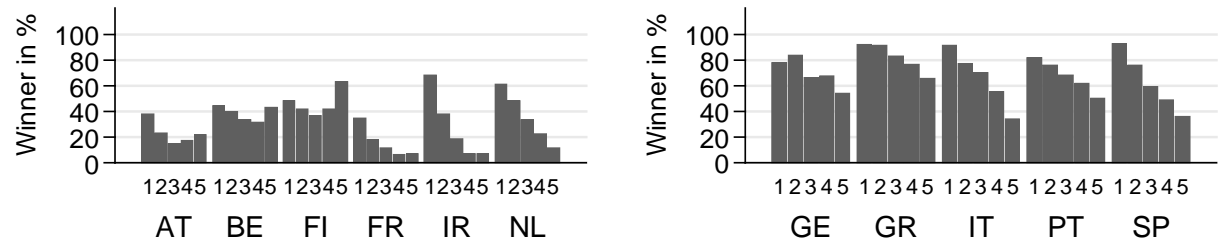

Source: Own calculations based on EUROMOD. 


\subsection{Automatic fiscal stabilisation}

What is the impact of introducing the EU system on the ability of the tax and transfer systems to act as an automatic stabiliser? Automatic fiscal stabilisation is associated with the ability of taxes and transfers to stabilise income and in consequence consumption automatically in the face of economic downturns. The stabilising character of the tax and transfer system relies on a simple mechanism: In the presence of a given negative shock to gross income, taxes decline and transfers increase, so that the decline in disposable income is smaller than the shock to gross income. Several components of government budgets are impacted by the macroeconomic situation in ways that operate to smooth the business cycle, with progressive income taxes and unemployment benefits being the most prominent example. Automatic stabilisation might have effects not only on disposable income but also on GDP itself. If in a recession fewer taxes are collected and more transfers are paid, this should support private incomes and dampen adverse movements in aggregate demand.

Of course, cushioning of shocks through taxes and transfers comes at the cost of an increase in the government budget deficit. The usual assumption is that this gap is closed through debt financing. However, in the current Eurozone debt crisis, some countries have lost access to private capital markets so that they need outside help to close the gap in the government budget. We will return to this issue further below.

The extent to which automatic stabilisers mitigate the impact of income shocks on household demand essentially depends on the tax and transfer system which determines the way in which a given shock to gross income translates into a change in disposable income. For instance, in the presence of a proportional income tax with a tax rate of $40 \%$, a shock on gross income of 100 Euros leads to a decline in disposable income of 60 Euros. In this case, the tax absorbs $40 \%$ of the shock to gross income. A progressive tax, in turn, would have a stronger stabilising effect (van den Noord, 2000; Girouard and André, 2005).

A common measure for estimating automatic stabilisation is the "normalised tax change" used by Auerbach and Feenberg (2000) which can be interpreted as "the tax system's built-in flexibility" (Pechman, 1973, 1987). Based on this idea, Dolls et al. (2012) define the "income stabilisation coefficient" which shows how changes in market income translate into changes in disposable income through changes in tax payments. They extend the concept of normalised tax change to include other taxes as well as social insurance contributions and transfers like e.g. unemployment benefits. We follow their approach and take into account personal income taxes (at all government levels), social insurance contributions as well as payroll taxes and transfers to private households such as unemployment benefits. In order to compute the coefficients of automatic stabilisation, we compute their income shock measure defined as a proportional decrease of gross income by $5 \%$ for all households. The results are presented in Table 4 . The levels and differences across countries in the baseline scenario are broadly in line with the calculations in Dolls et al. (2012). 
Tab. 4: Automatic fiscal stabilisation (income shock 5\%)

\begin{tabular}{ll|lll|lll}
\hline \hline & & \multicolumn{3}{|c|}{ EUavg } & \multicolumn{3}{c}{ EUavg_p } \\
& Baseline & Sc. 1 & Sc. 1cc & Sc. 2 & Sc. 1 & Sc. 1cc & Sc. 2 \\
\hline EU & 0.38 & 0.39 & 0.13 & 0.40 & 0.41 & 0.16 & 0.47 \\
AT & 0.31 & 0.34 & 0.14 & 0.41 & 0.33 & 0.12 & 0.37 \\
BE & 0.51 & 0.48 & 0.14 & 0.41 & 0.48 & 0.14 & 0.42 \\
FI & 0.46 & 0.44 & 0.13 & 0.40 & 0.45 & 0.14 & 0.42 \\
FR & 0.35 & 0.37 & 0.14 & 0.42 & 0.40 & 0.16 & 0.49 \\
GE & 0.47 & 0.46 & 0.15 & 0.44 & 0.46 & 0.14 & 0.42 \\
GR & 0.25 & 0.28 & 0.11 & 0.33 & 0.46 & 0.29 & 0.88 \\
IR & 0.38 & 0.39 & 0.13 & 0.39 & 0.45 & 0.20 & 0.59 \\
IT & 0.34 & 0.34 & 0.11 & 0.34 & 0.39 & 0.16 & 0.49 \\
NL & 0.38 & 0.39 & 0.14 & 0.41 & 0.36 & 0.10 & 0.31 \\
PT & 0.33 & 0.32 & 0.10 & 0.31 & 0.44 & 0.22 & 0.67 \\
SP & 0.27 & 0.29 & 0.11 & 0.34 & 0.37 & 0.19 & 0.57 \\
\hline \hline
\end{tabular}

Note: $S c .1 c c$ indicates credit constraints for countries.

Source: Own calculations based on EUROMOD.

When moving towards an EU tax-benefit system, most countries gain in terms of automatic stabilisation - except Belgium, Finland and Germany, which are the countries with the highest automatic stabilisers in their national tax and transfer systems. In the case of a fully integrated system (Sc. 2), the stabilisation coefficients are rather similar across countries - as cross country differences can only be due to different distributions of socio-economic characteristics. The qualitative results are rather similar for the scenarios with increased progressivity - except that now the Netherlands also have lower automatic stabilisers than in the baseline. The low income, southern European countries have significantly higher stabilisers in the progressive system. We can thus conclude that a more progressive EU tax system does not necessarily increase automatic stabilisers for all countries. For the high income countries, the opposite may occur.

How does an EU tax-benefit system cushion asymmetric shocks in individual countries? In the case of full integration, this cushioning is given by the stabilisation coefficient for $S c$. 2 , in the case of partial integration, by the coefficient of $S c .1$ if the country has unconstrained access to the credit markets in order to debt finance the stabilisation. However, should the respective country be credit-constrained, the picture changes. In the extreme case of no access to credit financing, national taxes and benefits have to be adjusted so that the income cushioning is zero, and automatic stabilisation only comes from the EU tax system, where the assumption is that the EU budget deficit can be financed by issuing debt. Hence, we re-compute the stabilisation 
coefficient for this case $(S c .1 c c)$. The results are approximately at one third of the cushioning of full integration and the cross country differences are again solely due to different characteristics distributions. The values for the income stabilisation coefficient range between 0.1 for Portugal and 0.15 for Germany. In the case of the more progressive EU system, the automatic stabiliser for Germany declines to 0.14 but that of Greece increases significantly, to 0.29 .

\subsection{Fiscal Equalisation}

We now turn to the second element of a fiscal union in our analysis, the introduction of a fiscal equalisation mechanism. Fiscal equalisation, in contrast to the creation of a common tax and transfer system, leaves the national tax and transfer systems in place but redistributes tax revenue across countries. This redistribution is based on the ability of a country to generate tax revenue, to which we refer as its taxing capacity. In existing fiscal equalisation systems this is a common approach (see e.g. Boadway, 2004, or Büttner, 2006). We define the taxing capacity of a country as the net tax revenue a country would raise if it fully applied the 'EU average' tax and transfer system used in the preceding section (compare Table 1, column 'Net taxes EUavg'). This taxing capacity can be interpreted as an indicator of the amount of tax revenue that could be raised by a country if tax rates and transfers were set as in other countries and serves as the basis for equalisation payments. Countries above (below) the average taxable capacity will pay (receive) transfers to (from) the equalisation mechanism. This setup can be interpreted as a simple version of a European 'transfer union'. Note that the scenario considered here is quite ambitious in that the fiscal equalisation scenario fully compensates for differences in taxing capacity. In practice one might expect a more moderate system which would compensate countries for a share of the differences in taxing capacity only.

It is clear that in such a system, a country as a whole either gains or loses, depending on whether the country is a net donor or recipient of fiscal equalisation payments. The distribution of taxes and transfers within a country, however, is less straightforward. For simplicity, and in order not to alter existing redistribution within a country, we assume that the equalisation of taxes and transfers are shared among households proportionally to existing net tax payments. What are the implications for automatic stabilisation properties of the tax and transfer system? Table 5 shows the net tax payments in the baseline as well as for the EU average system which serves as our measure of taxable capacity. The resulting fiscal equalisation payments are reported in column 3 (a positive (negative) value indicates a net contributing (receiving) country). Column 4 includes the new distribution of net taxes.

Consider first the direct cross country distributional effect of the fiscal equalisation system. As one would expect, the high income countries are net contributors to the system. Contributions per household range from 67.4 Euros in the case of Ireland to 17.7 Euros in Austria. These are huge contributions, equivalent to 9.6 per cent of gross income in Ireland and 3.2 per cent of gross income in Austria. Clearly, these unrealistically large contributions reflect the fact that the degree of fiscal equalisation is maximally large. Accordingly, the countries with below average taxing capacity receive huge transfers. The recipients include Greece, Portugal, Spain, Italy and France. In Greece the fiscal equalisation payment is equal to 86 Euros, an implausible 33 per cent of average gross income. France receives the lowest payment per household, just 8.51 Euros, which equals 1.7 per cent of average gross income. 
What are the implications of this system for automatic stabilisers? As long as governments can cushion income shocks by increasing debt financing, the stabilisers in the system are the same as under the national systems. But things are different if governments cannot borrow without restrictions. Consider an asymmetric shock in the form of a decline in gross incomes by $5 \%$ which hits the periphery of the Eurozone, i.e. the GIIPS countries. This corresponds to a 2\% shock at the EU level (column 5). The shock leads to a reduction in the net tax payments collected in the affected countries (column 6) as well as a reduction in their taxable capacity (column 7). As a result, the fiscal equalisation payments for all countries have to be adjusted (column 8) resulting in a new distribution of net taxes (column 9). Finally, column 10 reports the change in automatic stabilisation in the affected countries due to the fiscal equalisation mechanism compared to a pure national system.

Tab 5: 5\% asymmetric shock to GIIPS countries with fiscal equalisation mechanism

\begin{tabular}{|c|c|c|c|c|c|c|c|c|c|c|}
\hline & $\begin{array}{c}\text { Net } \\
\text { taxes } \\
\text { baseline }\end{array}$ & $\begin{array}{c}\text { Net } \\
\text { taxes } \\
\text { EUavg } \\
\end{array}$ & $\begin{array}{c}\text { Fiscal } \\
\text { eq. }\end{array}$ & $\begin{array}{c}\text { Fiscal } \\
\text { eq. } \\
\text { taxes }\end{array}$ & $\begin{array}{c}\text { Gross } \\
\text { income } \\
\text { shock \% }\end{array}$ & $\begin{array}{c}\text { New net } \\
\text { taxes } \\
\text { nat. }\end{array}$ & $\begin{array}{c}\text { New net } \\
\text { taxes } \\
\text { EUavg }\end{array}$ & $\begin{array}{l}\text { New } \\
\text { fiscal. } \\
\text { eq. }\end{array}$ & $\begin{array}{c}\text { New } \\
\text { fiscal } \\
\text { eq. taxes }\end{array}$ & $\begin{array}{c}\text { dAS } \\
\text { fiscal } \\
\text { eq. }\end{array}$ \\
\hline EU & 26.3 & 26.3 & 0.0 & 25.5 & 2 & 22.8 & 22.7 & 0.0 & 23.2 & 5 \\
\hline AT & 1.3 & 44.0 & 17.7 & 19.0 & 0 & 1.3 & 44.0 & 21.3 & 22.6 & 0 \\
\hline BE & 43.7 & 53.4 & 27.2 & 70.8 & 0 & 43.7 & 53.4 & 30.8 & 74.5 & 0 \\
\hline FI & 43.0 & 46.2 & 19.9 & 62.9 & 0 & 43.0 & 46.2 & 23.5 & 66.5 & 0 \\
\hline FR & -23.8 & 17.8 & -8.5 & -32.3 & 0 & -23.8 & 17.8 & -4.9 & -28.7 & 0 \\
\hline GE & 61.8 & 49.3 & 23.0 & 84.8 & 0 & 61.8 & 49.3 & 26.6 & 88.4 & 0 \\
\hline GR & 4.9 & -60.1 & -86.3 & -81.4 & 5 & 1.5 & -62.3 & -85.0 & -83.5 & -10 \\
\hline IR & 37.3 & 93.7 & 67.4 & 104.7 & 5 & 22.8 & 77.2 & 54.5 & 77.3 & 37 \\
\hline IT & 14.0 & 2.4 & -23.9 & -9.9 & 5 & 5.1 & -6.2 & -28.8 & -23.7 & 20 \\
\hline NL & 76.6 & 86.5 & 60.3 & 136.9 & 0 & 76.6 & 86.5 & 63.9 & 140.5 & 0 \\
\hline PT & 5.8 & -37.5 & -63.8 & -57.9 & 5 & 0.5 & -41.1 & -63.7 & -63.3 & 0 \\
\hline SP & -5.2 & -14.8 & -41.1 & -46.2 & 5 & -10.8 & -21.6 & -44.3 & -55.1 & 15 \\
\hline
\end{tabular}

Note: Monetary values are in weekly 2001 EUR; dAS indicates the change in automatic stabilisation in percentage points. Source: Own calculations based on EUROMOD.

Maybe the most striking result is that the fiscal equalisation system may have a destabilising, rather than a stabilising impact on some of the countries hit by the shock. In our scenario this applies to Greece, the country most favoured by the initial fiscal equalisation system. Although its fiscal capacity declines as a consequence of the shock, the payment it receives from the fiscal equalisation system declines from 86.3 to 85.0 Euros per household. The payment received by Portugal is almost unchanged. Only the countries which are closer to average taxing capacity experience a stabilising effect in the form of higher fiscal equalisation payments. The reason is that the shock has two effects on each affected country. Firstly, the taxing capacity of the country declines. Other things equal, this increases equalisation payments. But there is a second effect. Since other countries are affected by the shock, too, overall taxing capacity in the union declines as well. This reduces fiscal equalisation payments for all receiving countries. Together these two 
effects may imply that individual countries hit by the shock may end up receiving lower payments, so that the fiscal equalisation scheme has a destabilising, rather than a stabilising effect.

\section{Conclusions}

The current debt crisis in the Eurozone has brought the idea of deeper fiscal integration to the top of the European policy agenda. Many observers argue that the currency union cannot survive unless it is complemented by a 'fiscal union'. In this paper, we have analysed the economic effects of two important elements of fiscal integration, i) the introduction of an EUwide integrated tax and transfer system which partly or fully replaces the existing national systems and ii) the introduction of a system of fiscal equalisation.

Our analysis has led to the following results. The introduction of an EU tax and transfer system which replaces one third of the national systems would increase the disposable income of a small majority of households in Europe. At the same time it would lead to significant redistribution between countries. In Greece, Portugal, Spain, Italy and, surprisingly, Germany, a majority of household would benefit and average disposable income would increase. The gains range between 8 per cent of disposable income in Greece and just over one per cent in Germany. But in the remaining six countries, Austria, Belgium, Finland, France, Ireland and the Netherlands, a majority would lose. The highest loss occurs in Ireland, where average disposable income declines by 2.9 per cent. In many of the high income countries including Germany, the middle income quintiles fare worse as a result of the reform than households at the two ends of the income distribution. Choosing a more progressive variant of the EU tax system would change the magnitudes of gains and losses, but the patterns would be similar. All this suggests that generating political support for such a reform may be difficult.

Another key question is how the introduction of the EU tax-benefit system would affect automatic fiscal stabilisers in the different member countries. In the case, where the EU tax and transfer system replaces one third of the national systems, the EU system would absorb between 10 per cent (Portugal) and 15 per cent (Germany) of a shock to gross income. In the case of the more progressive EU tax system, the stabilisation properties change significantly. This system would absorb between 10 per cent (Netherlands) and 29 per cent (Greece) of an income shock. Given that replacing one third of the existing national tax and transfer systems by an EU system seems rather ambitious, and given that the more progressive system has stronger redistributive effects, which may reduce its political viability, this may seem disappointing. Estimates of fiscal stabilisers for the US suggest that the US federal income tax absorbs more than 30 per cent of an income shock (Eichengreen, 1990; Dolls et al., 2012). Of course, this reflects that the share of the US states in the income tax is rather small.

Regarding the implications of introducing a system of fiscal equalisation, our findings are even less appealing. We consider a system of strong fiscal equalisation, where differences between the taxing capacity of individual countries and average EU taxing capacity are fully neutralised. Unsurprisingly, this system leads to a massive transfer of tax revenue from high to low income countries. The transfers received by Greece amount to 33 per cent of gross household income in 
this country. In France, fiscal equalisation transfers received are 1.7 per cent of gross income. The highest relative burden is borne by the Netherlands, where contributions to the system are equal to 9.6 per cent of household gross income. These redistributive effects are much larger than those of introducing the common tax and transfer system, at least in the scenarios without increased progressivity, but the achievements in terms of macroeconomic stabilisation in the presence of asymmetric shocks are disappointing. For some countries, the fiscal equalisation mechanism even has a destabilising effect. An important policy implication of this analysis is that it is important to distinguish between the redistributive effects of steps towards fiscal integration and its stabilisation effects in the presence of an asymmetric macroeconomic shock.

These results should be interpreted in the light of the limitations of our analysis and the simplifying assumptions we have made. Most importantly, we should emphasise that our simulations focus on particular scenarios, and although we have looked at different variants of the reforms to explore robustness, the results do depend on the specific properties of the reforms we have considered, and other reforms will have different effects. This also applies to the macroeconomic shock scenarios we have analysed. We have focused on proportional income shocks which affect all households equally, but macroeconomic shocks often affect households very differently. As shown in Dolls et al. (2012), the impact of automatic fiscal stabilisers depends on the type of shock. We have also neglected the impact of reforms on indirect taxes and government expenditure other than monetary transfers.

Note also that our analysis abstracts from a number of behavioural effects apart from potential labour supply reactions that were taken into account. For instance, we have abstracted from potential effects of tax harmonisation on cross country migration. In addition, we did not take into account differences in the size of the shadow economy and the enforcement and collection of taxes across countries. Hence, given that there are considerable differences across countries, an important element of introducing a common tax system would be to address the issue of equal tax administration and enforcement. 


\section{References}

Atkinson, A. B. (2002). '1\% of €10,000 billion', in Townsend, P. and D. Gordon (eds). 'World poverty: New policies to defeat an old enemy', Policy Press, Bristol, 401-411.

Auerbach, A. and D. Feenberg (2000). 'The significance of federal taxes as automatic stabilizers', Journal of Economic Perspectives, 14, 37-56.

Bargain, O. (ed.) (2007). 'Micro-Simulation in Action - Policy Analysis in Europe Using EUROMOD', Research in Labor Economics, 25, Emerald, Bingley.

Bargain, O., C. Orsini and A. Peichl (2011). 'Labour Supply Elasticities in Europe and the US', IZA Discussion Paper No. 5820.

Beetsma, R. and L. Bovenberg (1998). 'Monetary Union without Fiscal Coordination May Discipline Policymakers', Journal of International Economics, 45, 239-258.

Beetsma, R. and M. Giuliodori (2010). 'The Macroeconomic Costs and Benefits of the EMU and Other Monetary Unions: An Overview of Recent Research', Journal of Economic Literature, 48, 603-641.

Begg, I. (2005). 'Funding the European Union. Making sense of the EU budget - A Federal Trust Report on the Union's Budget', The Federal Trust, London.

Begg, I (2011). 'An EU Tax - Overdue Reform or Federalist Fantasy?' Friedrich Ebert Stiftung, International Policy Analysis, February 2011.

Blundell, R., A. Duncan, J. McCrae and C. Meghir (2000). 'The labour market impact of the working families' tax credit', Fiscal Studies, 21 (1), 75-103.

Boadway, R. (2004). 'The Theory and Practice of Equalization', CESifo Economic Studies, 50 (1), 211-254.

Bordo, M., A. Markiewicz and L. Jonung (2011). 'A fiscal union for the Euro: Some lessons from history', NBER Working Paper No. 17380.

Buiter, W., G. Corsetti and N. Roubini (1993). 'Excessive Deficits: Sense and Nonsense in the Treaty of Maastricht', Economic Policy, 16, 57-100.

Büttner, T. (2006). 'The Incentive Effect of Fiscal Equalization Transfers on Tax Policy', Journal of Public Economics, 90, 477-497.

Cnossen, S. (2002). 'Tax Policy in the European Union: A review of issues and options', FinanzArchiv: Public Finance Analysis, 58, 466-558. 
Dixit, A. and L. Lambertini (2003). 'Symbiosis of Monetary and Fiscal Policies in a Monetary Union', Journal of International Economics, 60, 977-987.

Dolls, M., C. Fuest and A. Peichl (2012). 'Automatic Stabilizers and Economic Crisis: US vs. Europe', Journal of Public Economics, 96, 279 - 294.

Dullien, S. and D. Schwarzer (2005). 'The Eurozone under Serious Pressure - Regional Economic Cycles in the Monetary Union Need to Be Stabilised', SWP Comments 2005/C 22.

Eichengreen, B. (1990). 'One Money for Europe? Lessons from the US Currency Union', Economic Policy, 5 (10), 117-166.

Eichengreen, B. and C. Wyplosz (1998). 'The Stability Pact: More Than a Minor Nuisance?', Economic Policy, 13, 65-113.

Engwerda, J., B. van Arle and J. Plasmans (2002). 'Cooperative and Non-cooperative Fiscal Stabilisation Policies in the EMU', Journal of Economic Dynamics and Control, 26, 451-481.

Fuest, C. (2011). 'Will the reform of the institutional framework restore fiscal stability in the Eurozone?', CESifo Forum, 12 (2), 34-39.

Fuest, C. and A. Peichl (2012). 'European Fiscal Union: What is it? Does it work? And are there really 'no alternatives'?' CESifo Forum, 13 (1), 3-9.

Girouard, N. and C. André (2005), 'Measuring Cyclically-adjusted Budget Balances for OECD Countries', OECD Economics Department Working Papers No. 434.

Goodhart, C. A. E. (1998). 'The Two Concepts of Money: Implications for the Analysis of Optimal Currency Areas', European Journal of Political Economy, 14, 407-432.

Hammond, G. and J. von Hagen (1998). 'Regional Insurance against Asymmetric Shocks: An Empirical Study for the European Community', The Manchester School, 63, 331-353.

Hoynes, H. (1996). 'Welfare transfers in two-parent families: labour supply and welfare participation under AFDC-UP', Econometrica, 64(29), 295-332.

Italiener A. and M. Vanheukelen (1993). 'Proposals for Community Stabilization Mechanisms: Some Historical Applications', European Economy: Reports and Studies, 5, 493-510

Keen, M. (1993). 'The Welfare Economics of Tax Co-ordination in the European Community', Fiscal Studies, 14 (2), 15-36.

Keuschnigg, C. (2012). 'Should Europe Become a Fiscal Union?', CESifo Forum, 13 (1), 35-43.

Konrad, K. A. and H. Zschäpitz (2011). 'The future of the Eurozone?', CESifo Forum, 12 (2), 46-49. 
Lambert, P. (2011). 'Positional Equity and Equal Sacrifice: Design Principles for an EU-Wide Income Tax?', in Fleurbaey, M., M. Salles and J. A. Weymark (eds.). Social Ethics and Normative Economics - Essays in Honour of Serge-Christophe Kolm, Springer, Heidelberg.

Le Cacheux, J (2007). 'Funding the EU Budget with a Genuine Own resource: The Case for a European Tax', Notre Europe Studies, 57.

MacDougall, D. et al. (1977). Report of the Study Group on the Role of Public Finances in European Integration, Commission of the European Communities, Volume 1: General Report, Brussels, April 1977.

Masson, P. R. (1996). 'Fiscal Dimensions of Emu', The Economic Journal, 106 (437), 996-1004.

Marzinotto, B., A. Sapir and G. B. Wolff (2011). 'What Kind of Fiscal Union?', Bruegel Policy Briefs, 2011/06.

Oates, W.E. (1999). 'An Essay on Fiscal Federalism', Journal of Economic Literature, 37, 11201149.

Pechman, J. (1973). 'Responsiveness of the Federal Income Tax to Changes in Income', Brookings Papers on Economic Activity, 2, 385-421.

Pechman, J. (1987). 'Federal Tax Policy', Brookings Institution, Washington, $5^{\text {th }}$ ed.

Sapir, A. (2011). 'European Integration at the Crossroads: A Review Essay on the 50th Anniversary of Bela Balassa's Theory of Economic Integration', Journal of Economic Literature, $49,1200-1229$.

Schuknecht, L., P. Moutot, P. Rother and J. Stark (2011). 'The stability and growth pact: Crisis and reform', Occasional Paper Series , No. 129, European Central Bank 09/2011.

Sutherland, H. (2007). 'EUROMOD: the tax-benefit microsimulation model for the European Union', in Gupta, A. and A. Harding (eds.). 'Modelling Our Future: Population Ageing, Health and Aged Care', International Symposia in Economic Theory and Econometrics, 16, Elsevier, 483-488.

Uhlig, H. (2003). 'One Money, But Many Fiscal Policies in Europe: What Are the Consequences', in Buti, M. (ed.). 'Monetary and Fiscal Policy in EMU: Interaction and Coordination', Cambridge University Press, Cambridge, 29-64.

van den Noord, P. (2000): 'The size and role of automatic fiscal stabilisers in the 1990s and beyond', OECD Economics Department Working Papers No. 230.

van Soest, A. (1995). 'Structural models of family labour supply: a discrete choice approach', Journal of Human Resources, 30, 63-88. 
Wigger, B. and U. Wartha (2003). 'How to allocate the power to tax in Europe?', in Holler, M. J., H. Kliemt, D. Schmidtchen and M E. Streit (eds.). 'European Governance', Jahrbuch für Neue Politische Ökonomie, 22, Mohr Siebeck, Tübingen, 172-190.

Yitzhaki, S. (1979). 'Relative Deprivation and the Gini Coefficient', The Quarterly Journal of Economics, 93(2), 321-324. 


\section{APPENDIX}

\section{A Income changes without behavioural adjustments}

Tab. A.1: \% gainers, overall \%-change, mean gain and loss in weekly disposable income (2001 EUR) - for baseline labour supply

\begin{tabular}{|c|c|c|c|c|c|c|c|c|c|c|c|c|c|c|c|c|}
\hline & \multicolumn{4}{|c|}{ EUavg - Sc. 1} & \multicolumn{4}{|c|}{ EUavg - Sc. 2} & \multicolumn{4}{|c|}{ EUavg_p $-S c .1$} & \multicolumn{4}{|c|}{ EUavg_p - Sc. 2} \\
\hline & $\%+$ & $\% \mathrm{dY}$ & Gap+ & Gap- & $\%+$ & $\% \mathrm{dY}$ & Gap+ & Gap- & $\%+$ & $\% d Y$ & Gap+ & Gap- & $\%+$ & $\% d Y$ & Gap+ & Gap- \\
\hline EU & 51 & -0.2 & 14.6 & -16.7 & 51 & -0.5 & 43.8 & -50.1 & 50 & -0.2 & 15.2 & -17.5 & 50 & -0.6 & 45.6 & -52.4 \\
\hline AT & 23 & -2.6 & 16.3 & 3.9 & 23 & -7.8 & 48.8 & -71.7 & 21 & -2.7 & 16.2 & -23.5 & 21 & -8.2 & 48.6 & -70.4 \\
\hline $\mathrm{BE}$ & 34 & -1.3 & 19.5 & -20.6 & 34 & -4.0 & 58.4 & -61.8 & 32 & -1.5 & 18.7 & -20.6 & 32 & -4.6 & 55.9 & -61.8 \\
\hline FI & 46 & 0.0 & 14.4 & -12.4 & 46 & -0.1 & 43.2 & -37.2 & 44 & -0.2 & 13.7 & -12.3 & 44 & -0.6 & 41.1 & -37.0 \\
\hline FR & 13 & -2.8 & 8.0 & -17.4 & 13 & -8.4 & 23.9 & -52.2 & 14 & -2.8 & 8.1 & -17.6 & 14 & -8.4 & 24.2 & -52.8 \\
\hline GE & 70 & 1.0 & 12.9 & -14.0 & 70 & 3.1 & 38.8 & -41.9 & 69 & 0.8 & 11.7 & -12.9 & 69 & 2.5 & 35.1 & -38.8 \\
\hline GR & 82 & 8.1 & 27.8 & -10.0 & 82 & 24.2 & 8 & -30.1 & 80 & 8.9 & 3 & -1 & 80 & 26.6 & 94.5 & -34.1 \\
\hline IR & 27 & -2.9 & 20.8 & -34.5 & 27 & -8.8 & 62.4 & -103.4 & 27 & -3.2 & 25.5 & -38.8 & 27 & -9.6 & 76.5 & -116.3 \\
\hline IT & 64 & 0.7 & 12.6 & -12.5 & 64 & 2.2 & 37.8 & -37.5 & 64 & 0.9 & 14.6 & -14.6 & 64 & 2.6 & 43.9 & -43.9 \\
\hline NL & 35 & -0.6 & 15.8 & -13.9 & 35 & -1.9 & 47.4 & -41.8 & 35 & -1.0 & 18.7 & -18.8 & 35 & -3.0 & 56.2 & -56.4 \\
\hline PT & 68 & 4.4 & 26.9 & -13.9 & 68 & 13.3 & 80.7 & -41.6 & 67 & 4.9 & 30.6 & -15.3 & 67 & 14.7 & 91.8 & -46.0 \\
\hline SP & 57 & 0.0 & 16.4 & -21.7 & 57 & -0.1 & 49.1 & -65.2 & 58 & 0.2 & 19.2 & -24.3 & 58 & 0.5 & 57.6 & -72.9 \\
\hline
\end{tabular}

Note: $\%+$ is the percentage of reform gainers (100 minus \%+ is the percentage of reform losers); $\% \mathrm{dY}$ the overall \%-change in household weekly mean disposable income; Gap+ (Gap-) the mean difference from zero for positive (negative) dY. Source: Own calculations based on EUROMOD.

\section{B Behavioural adjustment}

We follow van Soest (1995), Hoynes (1996) and Blundell et al. (2000) in the choice of a structural discrete choice labour supply model and specify consumption-leisure preferences using a quadratic utility function as in Bargain et al. (2011). In contrast to traditional continuous labour supply models, discrete choice models allow to analyse both the extensive (participation) and the intensive (hours worked) labour supply decision within the same modelling framework. Using a discrete choice labour supply model has also the advantage to model nonlinear budget constraints as a result of, for example, nonlinear taxes, joint filing and unemployment benefits.

For the maximum likelihood estimation of the coefficients we assume that the hourly wage is constant across the working hour categories and does not depend on the actual working time which is standard in the literature. For unemployed people we estimate their (potential) hourly wages by using the Heckman correction for sample selection. The household's net disposable incomes for each working time category are computed using EUROMOD. After the consumption leisure preferences are estimated (see Bargain et al., 2011 for detailed results and estimated elasticities), the probabilities of changing working time categories due to a changed net income induced by the EU tax reform can be predicted. Then, the expected working hours for each individual as well the whole population are calculated. Results are reported in Table B.1. The 
first row shows results for the whole sample of countries while subsequently, figures on the national level are presented.

Tab. B.1: Mean hours worked, fulltime equivalents (FTE) and \%-changes in labour supply (FTE) - flexible singles and couples $(\mathrm{N}=30382)$

\begin{tabular}{ccc|cc|cc}
\hline & \multicolumn{2}{c}{ Baseline } & \multicolumn{4}{c}{ Reform scenarios } \\
& Hours worked & \multicolumn{2}{c}{ Change labour supply (FTE) in \% } \\
& Mean/ & FTE & \multicolumn{2}{c}{ EUavg } & \multicolumn{2}{c}{ EUavg_p } \\
& week & in Mio. & Sc. 1 & Sc. 2 & Sc. 1 & Sc. 2 \\
\hline EU & 29.9 & 71.1 & 0.0 & -0.7 & -0.5 & -2.3 \\
AT & 31.6 & 2.1 & 0.8 & 1.4 & 0.3 & -0.1 \\
BE & 31.7 & 2.6 & 3.6 & 8.2 & 2.9 & 6.2 \\
FI & 33.0 & 1.6 & 2.5 & 6.0 & 2.1 & 4.9 \\
FR & 30.8 & 17.3 & 0.5 & 1.3 & 0.3 & 0.6 \\
GE & 30.2 & 23.5 & 0.3 & 0.4 & -0.4 & -1.9 \\
GR & 25.5 & 1.3 & -2.7 & -8.9 & -3.3 & -11.0 \\
IR & 27.8 & 0.7 & -0.8 & -3.1 & -1.3 & -5.0 \\
IT & 27.0 & 8.4 & -1.3 & -4.5 & -1.8 & -6.2 \\
NL & 31.6 & 5.2 & -0.2 & -0.8 & -0.7 & -2.3 \\
PT & 34.3 & 2.0 & -0.1 & -0.6 & -0.3 & -1.3 \\
\hline \hline & 27.8 & 6.4 & -2.5 & -8.4 & -3.0 & -10.3 \\
\hline
\end{tabular}

Source: Own calculations based on EUROMOD. 


\section{Data sources}

Tab. C.1: Data sources used by EUROMOD

\begin{tabular}{|c|c|c|c|c|c|}
\hline \multirow[t]{2}{*}{ Country } & \multirow[t]{2}{*}{ Data } & \multicolumn{3}{|c|}{ Years } & \multirow{2}{*}{$\begin{array}{c}\text { No of observations } \\
\text { (original samples) }\end{array}$} \\
\hline & & $\begin{array}{l}\text { Data } \\
\text { collection }\end{array}$ & Incomes & $\begin{array}{l}\text { Simulated } \\
\text { policy }\end{array}$ & \\
\hline Austria & $\begin{array}{c}\text { European Community } \\
\text { Household Panel }\end{array}$ & 1999 & 1998 & 2001 & 7.386 \\
\hline Belgium & $\begin{array}{c}\text { Panel Survey on Belgian } \\
\text { Households }\end{array}$ & 2002 & 2001 & 2001 & 7.335 \\
\hline Finland & $\begin{array}{c}\text { Income Distribution } \\
\text { Survey }\end{array}$ & 2001 & 2001 & 2001 & 25.010 \\
\hline France & Household Budget Survey & $\begin{array}{c}2000- \\
01\end{array}$ & $\begin{array}{c}2000- \\
01\end{array}$ & 2001 & 25.803 \\
\hline Germany & $\begin{array}{c}\text { German Socio-Economic } \\
\text { Panel }\end{array}$ & 2001 & 2000 & 2001 & 16.874 \\
\hline Greece & Household Budget Survey & 1995 & 1994 & 2001 & 15.062 \\
\hline Ireland & Living in Ireland Survey & 2000 & 2000 & 2001 & 11.436 \\
\hline Italy & $\begin{array}{l}\text { Survey of Households } \\
\text { Income and Wealth }\end{array}$ & 1996 & 1995 & 2001 & 23.924 \\
\hline Netherlands & $\begin{array}{l}\text { Sociaal-Economisch } \\
\text { Panelonderzoek }\end{array}$ & 2000 & 1999 & 2001 & 10.344 \\
\hline Portugal & $\begin{array}{l}\text { European Community } \\
\text { Household Panel }\end{array}$ & 2001 & 2000 & 2001 & 13.092 \\
\hline Spain & $\begin{array}{c}\text { European Community } \\
\text { Household Panel }\end{array}$ & 2000 & 1999 & 2001 & 14.787 \\
\hline
\end{tabular}

